\title{
INVESTIGASI PEMBENTUKKAN IKATAN Zn-O RODS DI ATAS PERMUKAAN MIKROKANTILEVER DENGAN UJI KARAKTERISASI FTIR
}

\author{
Mia Yuliana Frestika ${ }^{1,2, a)}$, Rina Dewi Mayasari²,b) ${ }^{2}$ Masmui $^{2, \mathrm{c}}$, Agustanhakri ${ }^{2, \mathrm{~d}}$, \\ R. Ibrahim Purawiardi ${ }^{3, e)}$, Yuliasari ${ }^{3, f)}$, Ahmad Novi Muslimin ${ }^{3, g}$, \\ Muhammad Dani ${ }^{4, h)}$, Agus Setyo Budi ${ }^{1, \mathrm{i})}$, Ratno Nuryadi ${ }^{2, \mathrm{j})}$
}

${ }^{\text {I} P r o d i ~ F i s i k a, ~ F a k u l t a s ~ M a t e m a t i k a ~ d a n ~ I l m u ~ P e n g e t a h u a n ~ A l a m, ~ U n i v e r s i t a s ~ N e g e r i ~ J a k a r t a, ~ J l . ~ R a w a m a n g u n ~}$ Muka No 1, Jakarta 13220

${ }^{2}$ Pusat Teknologi Material, Badan Pengkajian dan Penerapan Teknologi, Gedung 224, Kawasan Puspiptek,Tangerang Selatan 15314

${ }^{3}$ Pusat Penelitian Fisika,Lembaga Ilmu Pengetahuan Indonesia, Gedung 441-442, Kawasan Puspiptek, Tangerang Selatan 15314

${ }^{4}$ Pusat Sains dan Teknologi Bahan Maju, Badan Tenaga Nuklir Nasional, Gedung 71, Kawasan Puspiptek, Tangerang selatan 15314

Email: a)miayuliana60@yahoo.com, ${ }^{\text {b) }}$ rina.dewi@bppt.go.id, ${ }^{\mathrm{c})}$ masmui@bppt.go.id, ${ }^{\mathrm{d})}$ agustanhakri@bppt.go.id, ${ }^{\text {e)}}$ rade026@lipi.go.id, ${ }_{2}{ }^{\text {f }}$ zulfa_yulia@yahoo.com, ${ }^{\text {g) }}$ ahmadnovimuslimin@ @otmail.com, ${ }^{\text {h) }}$ mdani@batan.go.id, i)agus_sb@unj.ac.id, j)ratno.nuryadi@bppt.go.id

\begin{abstract}
Abstrak
Pada riset ini, batang $\mathrm{ZnO}$ (Zinc Oxide rods) yang merupakan material pendeteksi objek gas ditumbuhkan di atas permukaan mikrokantilever dengan teknik hidrotermal. Sintesis ZnO rods ini meliputi dua proses, yaitu proses pelapisan lapisan benih (seed layer) menggunakan Zinc Asetate Dihydrate dengan metode dip-coating dan proses penumbuhan $\mathrm{ZnO}$ rods menggunakan Zinc Nitrate Tetrahydrate pada suhu $95{ }^{\circ} \mathrm{C}$ dengan variasi waktu 2 jam, 4 jam dan 6 jam. Kondisi pengeringan baik untuk lapisan benih dan penumbuhan $\mathrm{ZnO}$ rods dilakukan pada suhu $120{ }^{\circ} \mathrm{C}$ selama 2 jam. $\mathrm{ZnO}$ rods dikarakterisasi dengan teknik Fourier Transform Infrared (FTIR) untuk mengetahui pembentukan ikatan Zn-O. Hasil karakterisasi memperlihatkan bahwa korelasi logam oksida (metal oxide) ditunjukkan pada spektrum bilangan gelombang $540 \mathrm{~cm}^{-1}$ untuk waktu penumbuhan 2 jam, sementara ditunjukkan pada spektrum gelombang masing-masing $548 \mathrm{~cm}^{-1}$ dan $547 \mathrm{~cm}^{-1}$ untuk waktu penumbuhan $\mathrm{ZnO}$ rods 4 jam dan 6 jam. Spektrum bilangan gelombang sekitar $540-548 \mathrm{~cm}^{-1}$ tersebut diprediksi merupakan absorpsi dari pembentukan ikatan Zn-O.
\end{abstract}

Kata-kata kunci: Mikrokantilever, $\mathrm{ZnO}$ rods, dip-coating, hidrotermal, waktu penumbuhan

\begin{abstract}
In this work, $\mathrm{ZnO}$ (Zinc Oxide) rods, which is a sensitive material for gas detection, are grown on a microcantilever surface by hydrothermal technique. Synthesis of $\mathrm{ZnO}$ rods consists of two processes, i.e., a formation of seed layer using Zinc Acetate Dihydrate by a dip-coating and a growth of the $\mathrm{ZnO}$ rods using Zinc-Nitrate-Tetrahydrate at a temperature $95^{\circ} \mathrm{C}$ for time variations of 2 hours, 4 hours and 6 hours. Drying condition for both seed layer and growth of $\mathrm{ZnO}$ rods was done at a temperature of $120^{\circ} \mathrm{C}$ for 2 hours. The $\mathrm{ZnO}$ rods were then characterized by Fourier Transform Infrared (FTIR) in order to investigate the formation of $\mathrm{Zn}-\mathrm{O}$ bond. The characterization results indicate that the metal oxide
\end{abstract}


correlation is shown in the wavenumber spectrum of $540 \mathrm{~cm}^{-1}$ for a sample with 2-hour growth time, while the wavenumber spectrum of $548 \mathrm{~cm}^{-1}$ and $547 \mathrm{~cm}^{-1}$ for the growth time of $\mathrm{ZnO}$ rods for 4 hours and 6 hours. Wavenumber spectrum approximately at $540-548 \mathrm{~cm}^{-1}$ is predicted to be the absorption of the formation of a $\mathrm{Zn}-\mathrm{O}$ bond.

Keyword: Microcantilever, $\mathrm{ZnO}$ rods, dip-coating, hydrothermal, growth time dependent.

\section{PENDAHULUAN}

Mikrokantilever merupakan piranti teknologi MEMS (micro electro mechanical system) yang umum digunakan untuk deteksi gaya antar atom (atomic force) pada sistem AFM (Atomic Force Microscopy), dan akhir-akhir ini berpotensi digunakan untuk aplikasi sensor biologi dan kimia [1]. Mikrokantilever umumnya difabrikasi dengan menggunakan bahan dasar silikon yang memiliki panjang sekitar ratusan mikrometer, lebar puluhan mikrometer, tetapi mempunyai tebal hanya satu mikrometer. Mikrokantilever memiliki karakteristik sensing dengan sensitivitas tinggi hingga skala attogram $\left(10^{-18}\right)$ [2-4]. Untuk kegunaan aplikasi sensor, mikrokantilever didesain sangat lentur sehingga akan mudah terdefleksi (bending) jika terdapat target objek (molekul, partikel, atau sejenisnya) yang menempel pada permukaan mikrokantilever [5].

Untuk dapat mendeteksi suatu objek tertentu, mikrokantilever membutuhkan lapisan fungsional (bioreceptor) pada permukaannya. Karena itu, beberapa peneliti melakukan riset tentang pelapisan fungsional pada permukaan mikrokantilever tersebut. Pada tahun 2013, Thomas Contineau dkk. melakukan penelitian mengenai pelapisan mikrokantilever menggunakan bahan dasar Titanium Dioxide $\left(\mathrm{TiO}_{2}\right)$ dengan metode sputtering untuk mendeteksi gas yang mudah meledak contohnya karbit, fosfor dan bensin [6]. Tahun 2014, peneliti Turkey bernama Necmettin Killinc dkk. melakukan penelitian mikrokantilever yang dilapisi dengan Zinc Oxide $(\mathrm{ZnO})$ dapat mendeteksi senyawa organik yang mudah menguap (Volatile Organic Compounds) [7]. Dari riset yang telah dilakukan oleh beberapa penelitian di atas dapat disimpulkan bahwa mikrokantilever yang diberikan lapisan fungsional memiliki peluang untuk dapat digunakan sebagai pendeteksi objek tertentu.

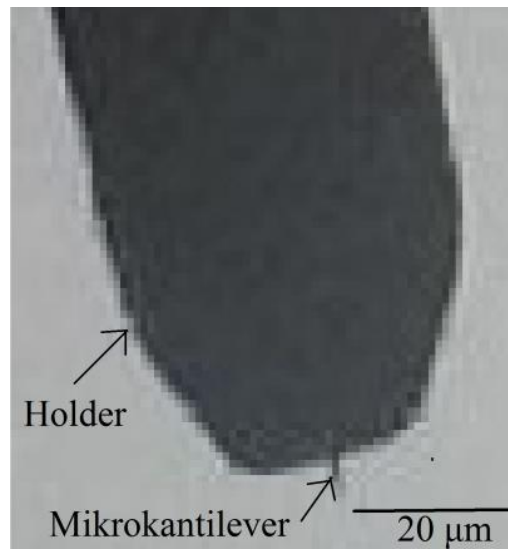

Gambar 1. Perbesaran mikrokantilever dengam microscope digital 200-400x

$\mathrm{ZnO}$ merupakan salah satu material yang menjanjikan pada beberapa aplikasi sensor karena memiliki respon yang sensitif. Dari sisi metode sintesis, pada tahun 2011, Singh dkk. meneliti mengenai efek terhadap pemanasan dan waktu penumbuhan $\mathrm{ZnO}$ rods dengan metode sol gel [8]. Tahun 2014, Kumar dkk. melakukan penelitian sintesis $\mathrm{ZnO}$ dengan bahan hexamethylenetetramin sebagai pelapisan (precipitant) dan zinc nitrate sebagai sumber (source) untuk membuat sel photovoltaic agar lebih sensitif terhadap warna [9].

Meskipun riset tentang sintesis $\mathrm{ZnO}$ telah dilakukan oleh beberapa grup peneliti [8,9], tetapi penumbuhan $\mathrm{ZnO}$ di atas mikrokantilever untuk aplikasi sensor masih jarang dilakukan [7], khususnya analisa kimiawi pembentukan ikatan $\mathrm{Zn}-\mathrm{O}$ di atas permukaan mikrokantilever. Jadi, tujuan riset ini untuk melakukan penumbuhan $\mathrm{ZnO}$ rods di atas permukaan mikrokantilever dengan metode 
hidrotermal dan analisa pembentukan ikatan Zn-O dengan menggunakan FTIR (Fourier Transform Infrared).

FTIR menggunakan prinsip spektro inframerah yang jika senyawa organik dikenai sinar inframerah dengan frekuensi tertentu (400-4000 $\left.\mathrm{cm}^{-1}\right)$, maka beberapa frekuensi diserap oleh senyawa tersebut. Banyaknya frekuensi yang melewati senyawa tersebut diukur sebagai persentasi transmisi (percentage transmittance). Setiap fekuensi sinar (termasuk inframerah) memiliki $\lambda$ tertentu yang dapat menunjukkan pembentukkan ikatan antar atom tertentu.[10]

\section{METODE PENELITIAN}

Proses penumbuhan $\mathrm{ZnO}$ rods pada penelitian ini menggunakan metode hidrotermal yang terdiri dari dua proses yaitu pelapisan seed layer dan proses penumbuhan $\mathrm{ZnO}$ rods. Secara detail proses penumbuhan dijelaskan sebagai di bawah ini.

\section{Proses pelapisan benih (seed layer) di atas permukaan mikrokantilever}

Bahan yang digunakan pada proses pelapisan benih (seed layer) di atas permukaan mikrokantilever yaitu Diethylamine $\left(\mathrm{C}_{4} \mathrm{H}_{11} \mathrm{~N}\right)$, Etylene Glycol Monomethyl $\left(\mathrm{C}_{4} \mathrm{H}_{10} \mathrm{O}_{2}\right)$, dan Zinc Acetate Dihydrate $\left(\mathrm{Zn}\left(\mathrm{O}_{2} \mathrm{CH}_{3}\right)_{2}\left(\mathrm{H}_{2} \mathrm{O}\right)_{2}\right)$ dengan konsentrasi $0,3 \mathrm{M}$. Mikrokantilever yang memiliki ukuran kecil (mikrometer) menyebabkan proses sintesis tidak mudah untuk dilakukan (gambar 1). Oleh karena itu, dilakukan pembuatan holder penjepit untuk mempermudah melakukan proses dipcoating. Holder penjepit dibuat dengan beberapa bahan yaitu akrilik, magnet, alumunium dan baut yang berbahan dasar besi. Pada gambar 2 dapat dilihat desain holder penjepit yang telah dibuat. Akrilik dilubangi kemudian magnet ditanam di dalamnya untuk menarik alumunium yang akan digunakan sebagai penjepit mikrokantilever. Pada gambar 2, dilakukan proses pencelupan (dipcoating) holder yang telah disiapkan dan mikrokantilever yang telah dipasang. Proses dip-coating dilakukan dengan cara mencelupkan holder beserta mikrokantilever ke dalam larutan kemudian dipindahkan ke gelas beaker kosong dalam waktu masing-masing 5 menit dengan pengulangan selama tiga kali. Setelah proses dip-coating, dilakukan pengeringan (drying) dengan suhu $120^{\circ} \mathrm{C}$ selama 2 jam.

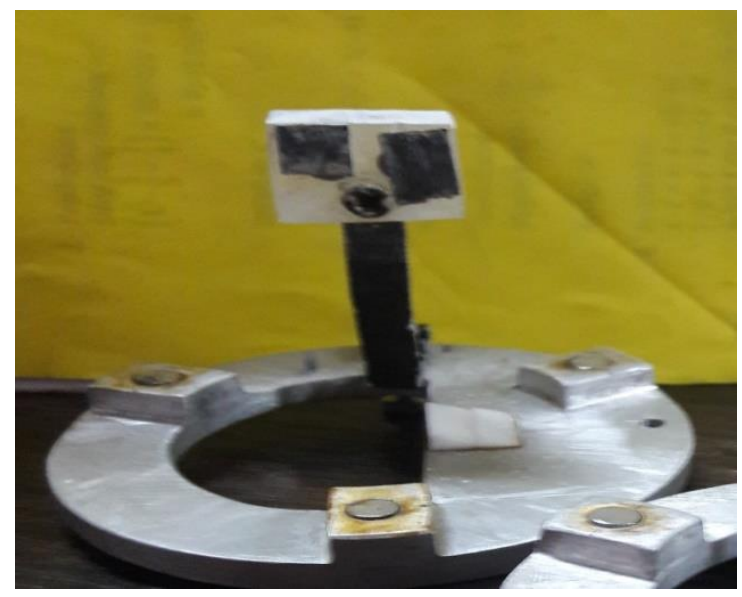

Gambar 2. Holder penjepit yang digunakan untuk proses dip-coating 


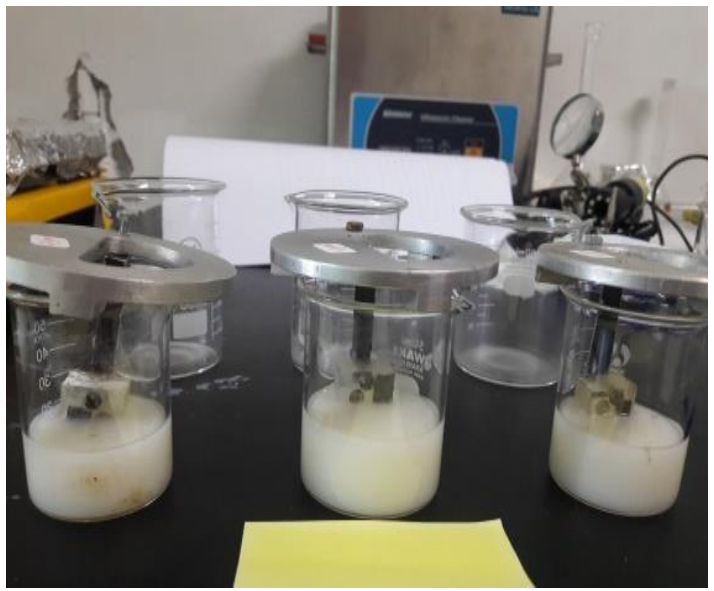

Gambar 3. Proses Dip coating mikrokantilever

\section{Penumbuhan $\mathrm{ZnO}$ rods di atas permukaan mikrokantilever}

Bahan yang digunakan pada proses penumbuhan batang $\mathrm{ZnO}(\mathrm{ZnO}$ Rods) di atas permukaan mikrokantilever yaitu Zinc Nitrate Tetrahydrate $\left(\mathrm{Zn}\left(\mathrm{NO}_{3}\right)_{2} .6 \mathrm{H}_{2} \mathrm{O}\right)$, Hexamethylene-tetramine $\left(\mathrm{C}_{6} \mathrm{H}_{12} \mathrm{~N}_{4}\right)$ dan Aqua Demineralitas (Aqua Dm) dengan konsentrasi 0,05 M. Penumbuhan $\mathrm{ZnO}$ di atas permukaan mikrokantilever menggunakan metode hidrotermal. Mikrokantilever yang telah dilakukan proses pelapisan dicelupkan ke dalam larutan dengan bahan dasar di atas untuk dilakukan proses penumbuhan. Proses penumbuhan $\mathrm{ZnO}$ menggunakan oven dengan suhu $95{ }^{\circ} \mathrm{C}$ selama waktu yang divariasikan yaitu 2 jam, 4 jam dan 6 jam. Catatan bahwa setelah proses penumbuhan $\mathrm{ZnO}$ seharusnya dilakukan proses annealing dengan suhu $300{ }^{\circ} \mathrm{C}$ sesuai referensi penumbuhan $\mathrm{ZnO}$ penelitian sebelumnya ${ }^{[7]}$, tetapi pada penelitian ini hanya dilakukan proses pengeringan dengan suhu $120{ }^{\circ} \mathrm{C}$ selama 1 jam dikarenakan bahan holder yang digunakan yaitu akrilik memiliki titik lebur dengan suhu $160{ }^{\circ} \mathrm{C}$. Oleh karena itu, pada proses ini tidak menggunakan furnace melainkan menggunakan oven. Pada proses penumbuhan $\mathrm{ZnO}$ dengan suhu $95{ }^{\circ} \mathrm{C}$, larutan mengendap dan endapan tersebut dilakukan pengeringan dengan suhu $120^{\circ} \mathrm{C}$ hingga endapannya membentuk serbuk yang digunakanan dalam proses karakterisasi.

\section{HASIL DAN PEMBAHASAN}

Gambar 4 menunjukkan skema gambar mikrokantilever dan hasil uji karakterisasi FE-SEM dari sample dengan waktu penumbuhan 2 jam pada perbesaran 50000x. Bentuk batangan-batangan merupakan batang material $\mathrm{ZnO}(\mathrm{ZnO}$ rods). Di sini, arah penumbuhan batang $\mathrm{ZnO}$ terlihat belum semua mengarah ke atas. Dengan kata lain, ada batang $\mathrm{ZnO}$ yang mengarah ke atas, arah miring dengan sudut tertentu, atau bahkan arah menyamping (horizontal). Tabel 1 menunjukkan sebaran ukuran diameter $\mathrm{ZnO}$ rods pada gambar FE-SEM. Dapat dilihat dari tabel 1 bahwa sebaran diameter penumbuhan $\mathrm{ZnO}$ rods untuk variasi waktu diameter 2 jam mempunyai interval $40-179 \mathrm{~nm}$. Diameter yang menunjukkan frekuensi terbesar yaitu pada ukuran 120-139 nm. 


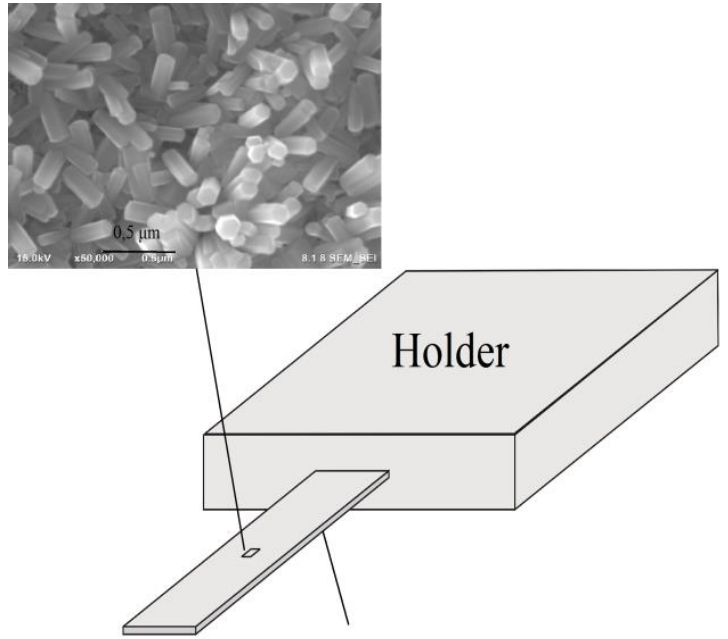

Mikrokantilever

Gambar 4. Skema Mikrokantilever dan hasil uji karakterisasi gambar FE-SEM (gambar atas) waktu penumbuhan 2 jam

Tabel 1. Interval ukuran diameter hasil FESEM ZnO rods waktu penumbuhan 2 jam.

\section{Interval ukuran (nm)}

$\begin{array}{cc}40-59 & 5 \\ 60-79 & 4 \\ 80-99 & 17 \\ 100-119 & 8 \\ 120-139 & 84 \\ 140-159 & 4 \\ 160-179 & 2\end{array}$

Gambar 5 menunjukkan spektrum FTIR dari bahan dasar penumbuhan batang ZnO (ZnO Rods) yaitu Zinc Nitrate Tetrahydrate $\left(\mathrm{Zn}\left(\mathrm{NO}_{3}\right)_{2} \cdot 6 \mathrm{H}_{2} \mathrm{O}\right)$, dan juga spektrum FTIR endapan penumbuhan batang $\mathrm{ZnO}$ dengan waktu 2 jam, 4 jam dan 6 jam. Panjang gelombang $540 \mathrm{~cm}^{-1}$ menunjukkan pembentukkan ikatan $\mathrm{Zn}-\mathrm{O}$ untuk waktu penumbuhan 2 jam, sementara panjang gelombang masing-masing $548 \mathrm{~cm}^{-1}$ dan $547 \mathrm{~cm}^{-1}$ untuk waktu penumbuhan batang $\mathrm{ZnO}(\mathrm{ZnO}$ rods $) 4$ jam dan 6 jam. Diketahui dari publikasi sebelumnya ${ }^{[11]}$ bahwa spektrum bilangan gelombang penumbuhan $\mathrm{ZnO}$ nanopartikel adalah $532 \mathrm{~cm}^{-1}$.
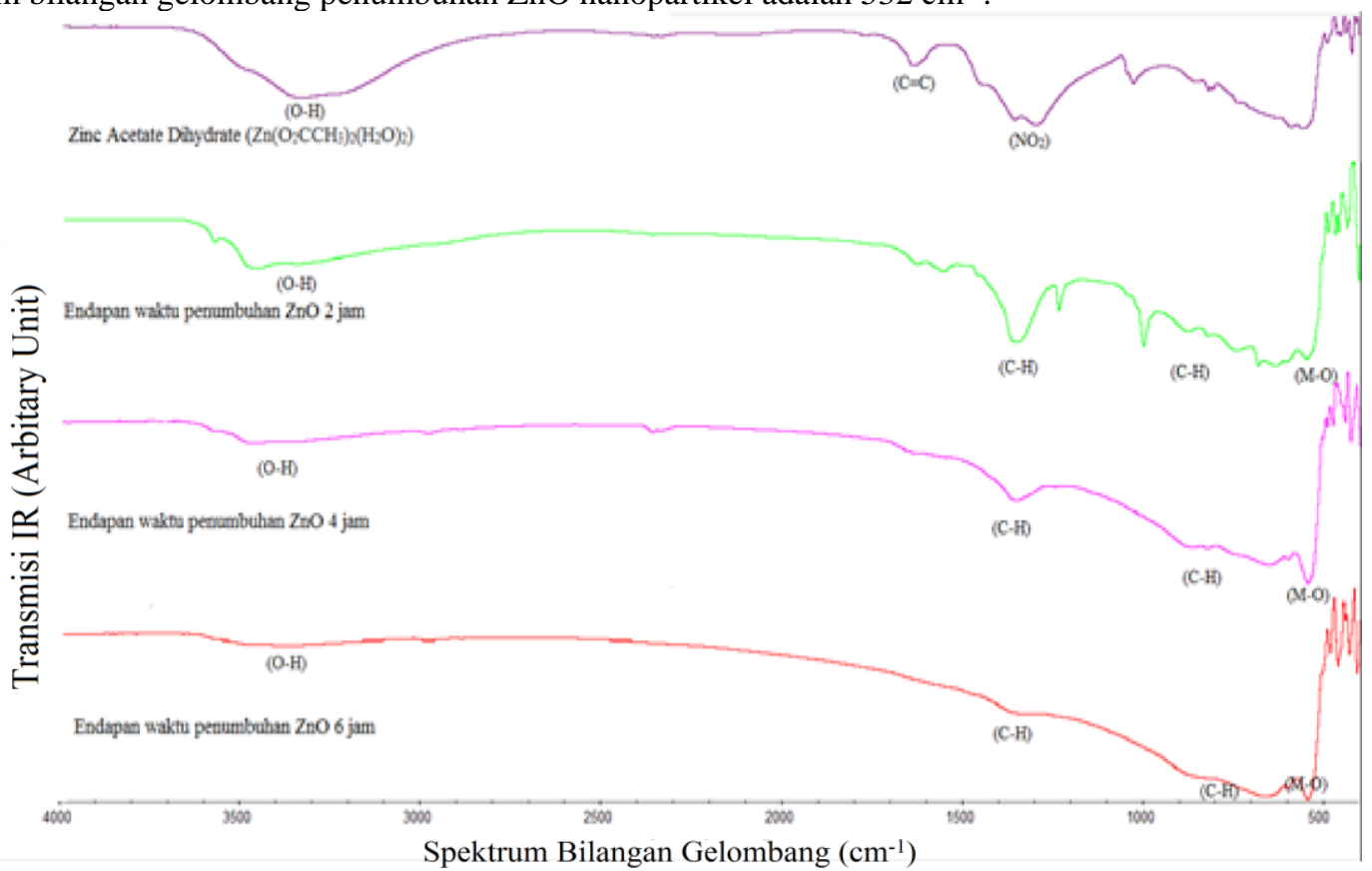

Gambar 5. Spektrum dari Zinc Nitrate Tetrahydrate $\left(\mathrm{Zn}\left(\mathrm{NO}_{3}\right)_{2} .6 \mathrm{H}_{2} \mathrm{O}\right)$ dan endapan larutan $\mathrm{ZnO}$ yang digunakan untuk penumbuhan selama 2 jam, 4 jam dan 6 jam 
Tabel 2.Peak (puncak/lembah) yang timbul pada bahan dasar Zinc Nitrate Tetrahydrate Absorpsi IR $\left(\mathrm{cm}^{-1}\right)$

Ikatan yang menyebabkan penyerapan

\begin{tabular}{lc}
\hline 3337,20 & O-H \\
1637,35 & $\mathrm{C}=\mathrm{C}$ \\
1357,22 & $\mathrm{NO}_{2}$ \\
\hline
\end{tabular}

(absorpsi)

Tabel 3. Peak (puncak/lembah) yang timbul untuk waktu endapan penumbuhan $\mathrm{ZnO} 2$ jam

\begin{tabular}{cc}
\hline Absorpsi IR $\left(\mathbf{c m}^{-\mathbf{1}}\right)$ & $\begin{array}{c}\text { Ikatan yang menyebabkan penyerapan } \\
\text { (absorpsi) }\end{array}$ \\
\hline 3347,18 & $\mathrm{O}-\mathrm{H}$ \\
1368,78 & $\mathrm{C}-\mathrm{H}$ \\
881,69 & $\mathrm{O}-\mathrm{H}$ \\
540,96 & $\mathrm{M}-\mathrm{O}(\mathrm{Zn}-\mathrm{O})$ \\
\hline
\end{tabular}

Tabel 4. Peak (puncak/lembah) yang timbul untuk waktu endapan penumbuhan $\mathrm{ZnO} 4$ jam

\begin{tabular}{cc}
\hline Absorpsi IR $\left(\mathbf{c m}^{-\mathbf{1}}\right)$ & $\begin{array}{c}\text { Ikatan yang menyebabkan penyerapan } \\
\text { (absorpsi) }\end{array}$ \\
\hline 3455,96 & $\mathrm{O}-\mathrm{H}$ \\
1356,20 & $\mathrm{C}-\mathrm{H}$ \\
825,69 & $\mathrm{C}-\mathrm{H}$ \\
548,27 & $\mathrm{M}-\mathrm{O}(\mathrm{Zn}-\mathrm{O})$ \\
\hline
\end{tabular}

Tabel 5. Peak (puncak/lembah) yang timbul untuk waktu endapan penumbuhan $\mathrm{ZnO} 6$ jam

\begin{tabular}{cc} 
Tabel 5. Peak (puncak/lembah) yang timbul untuk waktu endapan penumbuhan ZnO 6 jam \\
\hline Absorpsi IR $\left(\mathbf{c m}^{-\mathbf{1}}\right)$ & $\begin{array}{c}\text { Ikatan yang menyebabkan penyerapan } \\
\text { (absorpsi) }\end{array}$ \\
\hline 3369,97 & $\mathrm{O}-\mathrm{H}$ \\
1355,73 & $\mathrm{C}-\mathrm{H}$ \\
820,58 & $\mathrm{C}-\mathrm{H}$ \\
547,27 & $\mathrm{M}-\mathrm{O}(\mathrm{Zn}-\mathrm{O})$ \\
\hline
\end{tabular}

Dari Tabel 2-5 dapat dilihat beberapa ikatan yang menyebabkan adanya penyerapan (absorpsi) pada bahan dasar Zinc Nitrate Tetrahydrate yaitu $\mathrm{O}-\mathrm{H}, \mathrm{C}=\mathrm{C}, \mathrm{NO}_{2}$. Sedangkan ikatan yang menyebabkan penyerapan (absorpsi) pada endapan waktu penumbuhan 2 jam, 4 jam dan 6 jam adalah O-H, C-H dan Metal Oxide (M-O) yang diprediksi sebagai Zinc Oxide (ZnO). Ikatan O-H yang terserap pada daerah spektrum bilangan gelombang sekitar $3300 \mathrm{~cm}^{-1}$ semakin mengecil jika waktu penumbuhan batang $\mathrm{ZnO}(\mathrm{ZnO}$ rods) semakin lama. Hal tersebut juga terjadi pada ikatan C-H dan O$\mathrm{H}$ di daerah spektrum lainnya. Sedangkan ikatan $\mathrm{C}=\mathrm{C}, \mathrm{NO}_{2}$ sudah tidak ada penyerapan lagi pada endapan dengan waktu penumbuhan 2 jam, 4 jam dan 6 jam. Ikatan Metal Oxide (M-O) yang diprediksi sebagai ikatan Zn-O terdapat pada spektrum bilangan gelombang antara $540-548 \mathrm{~cm}^{-1}$. Karena itu, analisa karakterisasi FTIR ini mengkonfirmasi ikatan Zn-O pada penumbuhan ZnO dalam penelitian ini.

\section{SIMPULAN}

Telah dilakukan penumbuhan material $\mathrm{ZnO}$ di atas permukaan mikrokantilever dan investigasi dengan menggunakan FTIR. Gugus fungsi dari pengujian FTIR dilakukan menggunakan serbuk endapan penumbuhan batang $\mathrm{ZnO}(\mathrm{ZnO}$ rods). Uji karakterisasi FTIR mendapatkan hasil bahwa beberapa spektrum bilangan gelombang yang muncul sebagai respon dari ikatan antar atom tertentu. Ikatan logam oksida yang terbentuk dari bahan dasar penumbuhan batang $\mathrm{ZnO}$ ( $\mathrm{ZnO}$ rods) merupakan Zinc Nitrate Tetrahydrate $\left(\mathrm{Zn}\left(\mathrm{NO}_{3}\right)_{2} \cdot 6 \mathrm{H}_{2} \mathrm{O}\right)$. Dengan waktu penumbuhan yang semakin lama yaitu 2 jam, 4 jam dan 6 jam, ikatan $\mathrm{O}-\mathrm{H}$ dan $\mathrm{C}-\mathrm{H}$ semakin berkurang tingkat penyerapannya (absorpsi). Pembentukan ikatan atom $\mathrm{Zn}-\mathrm{O}$ untuk ketiga sample $\mathrm{ZnO}$ rods (waktu penumbuhan 2 jam, 4 jam dan 6 jam) ditunjukkan dengan spektrum bilangan gelombang sekitar 540-548 $\mathrm{cm}^{-1}$. 


\section{UCAPAN TERIMAKASIH}

Terimakasih kepada Kemenristekdikti atas hibah riset Intensif Sinas 2017 yang telah membantu riset ini. Terimakasih kepada kak Fitri yang telah membantu uji karakterisasi FTIR.

\section{REFERENSI}

[1] Nardo Ramírez Frómeta, "Cantilever Biosensors", Biotecnología Aplicada Vol.23, No. 4, 2006.

[2] Raiteri, R.Grattarola M, Butt, H.Skladal,P. (2001), Micromechanical cantilever-based biosensor, Sensor and Actuators B, Vol. 79, halaman 115-126.

[3] Vashist, S.K (2007), A review of Microcantilevers for sensing Aplications, Journal of Nanotechnology, Vol. 3, halaman 1-15.

[4] Dohn, S.Sandberg, W, Boisen, A. (2005), Enhanced functionality of cantilever based mass sensors using higher modes, Applied physics Letter, Vol. 86, halaman 233-501.

[5] Ratno N, Lia A (2013), Desain dan Pengukuran Gas dengan Mikrokantilever Piezoresistif melalui mode dinamis dan statis. Prosiding InSinas 2012.

[6] T. Contineau, Sergey N. Pronkin dkk., (2013), Synthesis of vertically aligned titanium dioxide nanotubes on microcantilevers for new nanostructured micromechanical sensors for explosive detection. Sensors \& Actuators : B. Chemical. Vol. 182, Halaman 489-497.

[7] N. Killinc, O. Cakmak (2014), Fabrication of 1D ZnO nanostructures on MEMS cantilever for VOC sensor application, Sensors and Actuators B: Chemical. Vol.202, Halaman 357-364.

[8] Neha Singh dkk., (2012), effect of heat and time-period on the growth of $\mathrm{ZnO}$ nanorods by sol-gel technique, Optik-Internationl Journal for Light and Electron Optics, Volume 123, Issue 15, Halaman 1340-1342.

[9] S. Kumar dkk., (2014), Synthesis of ZnO Nanorods using Hydrotermal Methodfor natural Dye Sensitized Photovoltaic Cell.

[10] Pavia, D.L Lampman, G.H dan Kriz, G.S. 2001. Introduction to Spectroscopy 3th ed. USA : Thomson Learning.

[11] Samira Bagheri dkk., (2013), Facile Synthesis of nano-sized $\mathrm{ZnO}$ by direct precipitation method. Scholars Research Library, Der Pharma Chemica 5(3):265-270. 
